月

\title{
Enzymatic Activity of Protease Producing Bacteria from Tofu Waste
}

\author{
Isma Kurniatanty ${ }^{1)^{*}}$ and Esti Wahyu Widowati ${ }^{2)}$ \\ UIN Sunan Kalijaga Yogyakarta, Indonesia \\ isma.kurniatanty@uin-suka.ac.id
}

\begin{abstract}
Protease is an enzyme with high economic value and has been used in industries. Much natural waste can be considered as promising sources protease producing bacteria, such as tofu waste. The objective of the present study was to screen and isolate protease producing bacteria from tofu waste collected from Yogyakarta. Tofu waste samples were serially diluted and $0.1 \mathrm{ml}$ of sample was spread on skim milk agar, at $37^{\circ} \mathrm{C}$ for 48 hours. Four bacterial colonies showed a clear zone around the colony, indicating protease activity. These isolates (encoded as TWB-1, TWB-2, TWB-3, and TWB-4) were subjected to several biochemical tests and gram staining. Protease activity was determined using the tyrosine standard curve with the casein-Hammarsten substrate. Protease activity of TWB-1, TWB-2, TWB-3, and TWB-4 were 2.85, 5.74, 5.14, and 3.00 respectively. Isolate TWB-2 showed the maximum protease activity with $5.74 \mathrm{U} / \mathrm{ml}$.
\end{abstract}

\section{Introduction}

Protease is an enzyme that can be found in all living organisms because of its important physiological function. It is also considered as one of the most useful enzymes in industrial processes. Proteases catalyze hydrolysis peptide bonds in protein and have been applied widely in pharmaceuticals, textile, leather, and food industries (Beynon \& Bond, 2001; Palmer, 1995)

Proteases are ubiquitously found in many sources such as plants, animals, and microorganisms. Bacillus has been well known as the source of extracellular protease from microorganisms. Protease can be isolated either as extracellular protein or intracellular protein. Protease from microorganisms showed more varieties compared to those from plants and animals. Therefore, microbial sources are preferred for protease production due to technical and economic advantages (Rao et al., 1998; Whitaker, 1996).

Natural sources are considered as potential promising sources for bacterial producing protease. Tofu waste is a natural source for protease producing bacteria because of its content of high protein, which is a good nutrient for protease bacteria. The objective of the present study was to screen and isolate protease producing bacteria from tofu waste collected from Yogyakarta. 


\section{Materials and Methods}

Tofu liquid waste was obtained from the home industry producing tofu in Bantul Yogyakarta, skim milk (Greenfield), peptone, NaCl, Nutrien Broth (NB) medium, tyrosine (Merck, 1.083710025), Na2CO3, Folin-Ciocalteau (Merck, 1.09001.0500).

\subsection{Isolation and screening of protease-producing bacteria}

Tofu liquid waste samples were inoculated into the nutrient broth (NB) medium and incubated for 24 hours at $37^{\circ} \mathrm{C}$. After some serial dilution, $0.1 \mathrm{ml}$ of the sample from the NB medium was spread on skim milk agar medium, incubated for 24 hours at $37^{\circ} \mathrm{C}$. Bacteria with clear zones around the colonies which indicating protease activity were chosen as potent protease-producing bacteria.

\subsection{Identification and characterization of bacteria}

Biochemical and morphological tests (cell observation) were carried out for bacterial identification. The four selected bacteria (encoded as TWB-1, TWB-2, TWB-3, and TWB-4) were subjected to several biochemical tests (catalase test, indole production, starch hydrolysis and sugar fermentation (glucose, sucrose, and lactose)) and morphological test (form and color of the colony, motility, and gram staining).

\subsection{Protease production and extraction}

One loop of bacteria was inoculated into LB medium and incubated in incubator shaker (130 rpm, $37^{\circ} \mathrm{C}$ for $72 \mathrm{jam}$ ). After 72 hours, the culture was centrifuged at $10.000 \mathrm{rpm}$ for 15 minutes to separate between the enzyme and its substrate. The filtrate was then used for protease activity test.

\subsection{Protease Activity}

Protease activity was determined using the tyrosine standard curve with the casein-Hammarsten substrate. Protease activity was measured using Casein Hammarsten as a substrate ( $2 \%$ casein in 0.05 $\mathrm{M}$ phosphate buffer solution $\mathrm{pH} 7.0$ ). $0.5 \mathrm{ml}$ of enzyme solution was added to $0.5 \mathrm{ml}$ of $0.05 \mathrm{M}$ solution of phosphate buffer $\mathrm{pH} 7$ and incubated at $37^{\circ} \mathrm{C}$ for 5 minutes. The next $0.5 \mathrm{ml}$ substrate was added. The reaction mixture was re-incubated at $37^{\circ} \mathrm{C}$ for 10 minutes. The reaction was stopped by adding 1 $\mathrm{ml}$ of $0.4 \mathrm{M}$ Trichloroacetic acid (TCA). Furthermore, the supernatant was separated from the precipitate using Whatman paper no. $1.0 .5 \mathrm{ml}$ of filtrate added with $2.5 \mathrm{ml}$ of $0.5 \mathrm{M}$ sodium carbonate, preincubated for 10 minutes then $0.5 \mathrm{ml}$ of FolinCiocalteau reagent are added and re-incubated for 30 minutes. The optical density (OD) was examined at $660 \mathrm{~nm}$. As a blank, the enzyme solution was used with the same treatment, but TCA was added before the addition of the substrate. One unit of protease enzyme activity is the number of enzymes needed to produce 1 microgram of tyrosine (Bergmeyer et al., 1983)

\section{Results and Discussion}

\subsection{Isolation and screening of protease-producing bacteria}

Tofu waste is one potential source of protein. Tofu waste still has high levels of protein which allow indigenous protease-producing microorganisms to grow inside (Sulistyaningtyas et al., 2017). 
Screening of proteolytic bacteria was performed on $1 \%$ skim milk agar plates. The proteolytic activity showed by clear zones around the colony (Fig. 1) is This clear zone occurs due to the termination of peptide bonds in proteins by proteases (Suhartono, 1992). Proteolytic bacteria produce protease enzymes that can hydrolyze peptide bonds to amino acids. Casein in the skim milk agar medium is a substrate for protease enzymes (Akhdiya, 2003).

Connelly et al. (2004) stated that substrates are needed to produce extracellular protease enzymes. Enzyme production increase if there are suitable substrates around them. If there are no suitable substrates, the enzyme will be produced in small amounts.
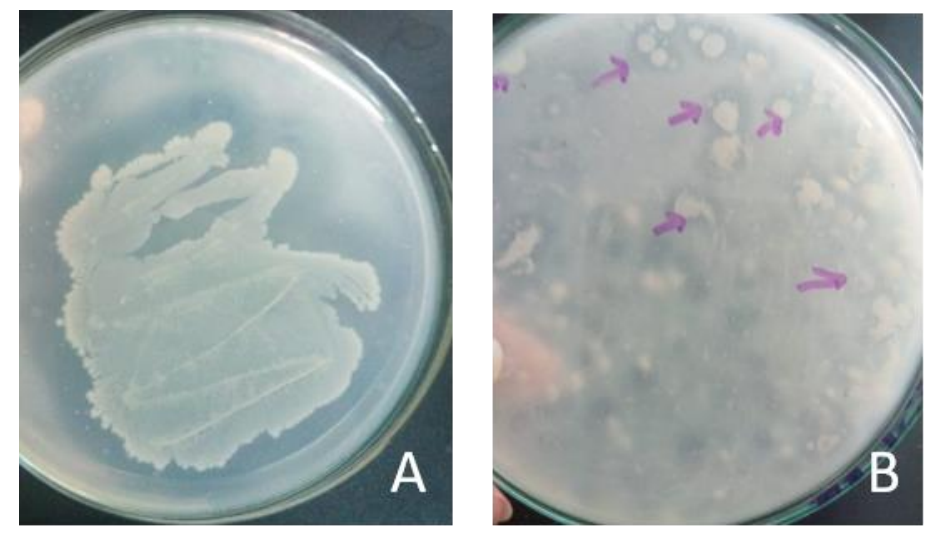

Figure 1: Tofu waste samples were serially diluted (A) and $0.1 \mathrm{ml}$ of sample was spread on skim milk agar, at $37^{\circ} \mathrm{C}$ for 48 hours (B). The bacterial colonies showed a clear zone around the colony, indicating protease activity.

\subsection{Identification and characterization of bacteria}

Characterization of the colony, gram staining, and motility are showed in table 1, whereas the biochemical test results are presented in Table 2. The colonies' form of the selected isolates was circular, irregular, and small circular, while the colonies' color was dominated by white and beige. Three isolates (TWB-2, TWB-3, and TWB-4) were motile. Three isolates (TWB-1, TWB-2, TWB-3) were grampositive bacteria, whereas TWB-4 was a gram-negative bacteria.

\begin{tabular}{|c|c|c|c|c|}
\hline \multirow{2}{*}{$\begin{array}{l}\text { Isolate } \\
\text { number }\end{array}$} & \multicolumn{2}{|c|}{ Colony morphology } & \multirow{2}{*}{ Motility } & \multirow{2}{*}{$\begin{array}{c}\text { Gram } \\
\text { staining }\end{array}$} \\
\hline & Form & Colour & & \\
\hline TWB-1 & circular & white & - & + \\
\hline TWB-2 & circular & cream & + & + \\
\hline TWB-3 & irregular & white & + & + \\
\hline TWB-4 & small circular & white & + & - \\
\hline
\end{tabular}

Table 1: The morphology of four selected bacteria are diverse one to another.

Some biochemical tests carried out were for identification are catalase test, indole production, starch hydrolysis, and sugar fermentation (glucose, sucrose, and lactose). All isolates were positive on the catalase test, indicated that all isolate were aerobic or facultative anaerobic bacteria (Holt et al., 1994 and Marlina, 2009). All isolates also showed a positive result on the sugar fermentation test but gave negative results on the indole test. These results indicated the bacteria were not forming indole. Two 
isolates (TWB-2 and TWB-3) showed positive results in the starch test, while TWB-2 and TWB-4 showed negative results.

\begin{tabular}{ccccccc}
\hline \multirow{2}{*}{$\begin{array}{c}\text { Number of } \\
\text { Isolates }\end{array}$} & \multicolumn{6}{c}{ Biochemical characters } \\
\cline { 2 - 7 } & Catalase & $\begin{array}{c}\text { Indole } \\
\text { Production }\end{array}$ & $\begin{array}{c}\text { Starch } \\
\text { hydrolysis }\end{array}$ & Glucose & Sucrose & Lactose \\
\hline TWB-1 & + & - & - & + & + & + \\
TWB-2 & + & - & + & + & + & + \\
TWB-3 & + & - & + & + & + & + \\
TWB-4 & + & - & - & + & + & + \\
\hline
\end{tabular}

Table 2: Biochemical characters of four selected bacteria

\subsection{Protease Activity}

The results of protease enzyme activity are TWB-1, TWB-2, TWB-3 and TWB-4 2.85, 5.74, 5.14, and 3.00 Units / mL (Fig.2).

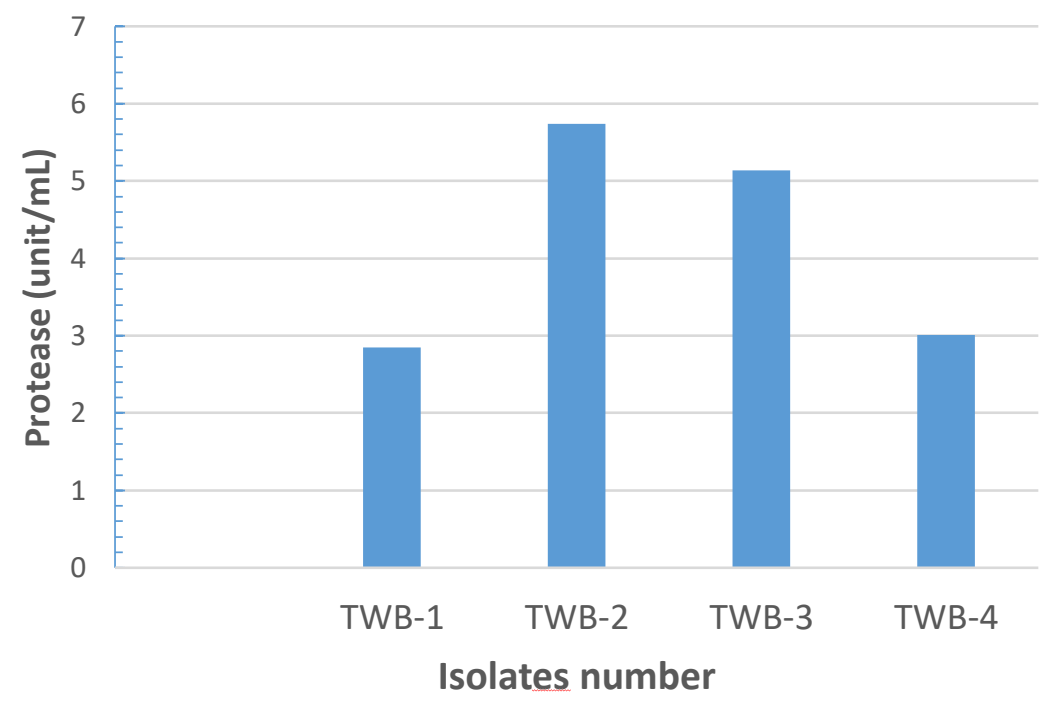

Figure 2: Protease activity of four selected bacteria was determined using Casein Hammersten as a substrate. TWB-2 showed the highest activity with $5.74 \mathrm{U} / \mathrm{ml}$

The activity of protease depends on the nutrients (protein) in the medium. Protease can degrade proteins into amino acids. High protease activity is due to the abundance of protein sources used as substrates. The amount of substrate is an important factor in proteolytic activity. The high substrate in the medium will form an enzyme-substrate complex which will increase the catalytic rate of the enzyme. Conversely, if the amount of substrate is small, it will inhibit the formation of enzyme-substrate complexes. This condition could change the enzyme structure which will decrease the catalytic rate. Due to changes in enzyme structure, the active site of the enzyme changes shape so that it becomes less functional in binding the substrate (Yunita, 2012).

Lehninger (1995) stated that enzymes have high specificity for the substrates. The reaction will occur on the active side of enzymes with substrates through a specific bond. Protease activity also 
depends on the genus of bacteria. Each species has a different activity to degrade protein in a medium because they produce different enzymes (Muchtadi \& Betty, 1983).

\section{Conclusions}

Tofu waste is a potential source for bacterial producing protease. Among the four selected isolates (encoded as TWB-1, TWB-2, TWB-3, and TWB-4), TWB-2 showed the maximum protease activity with $5.74 \mathrm{U} / \mathrm{ml}$.

\section{References}

Akhdiya A. (2003). Isolasi Bakteri Penghasil Enzim Protease Alkalin Termostabil. Buletin Plasma Nutfah. 9: 98-102.

Bergmeyer HU, Bergmeyer J, Graß1 M. (1983). Methods of Enzymatic Analysis Vol 2. Weinheim: Verlag Chemie

Beynon, R., \& Bond, JS. (2001). Proteolytic Enzymes. 2nd ed. New York. Oxford University Press Connelly MB, Young GM, Sloma A. (2004). Extracellular proteolytic activity plays a central role in swarming motility in Bacillus subtilis. J. Bacteriol. 186: 4159-4167.

Holt JG, Krig NR, Sneath P, Staley J, \& Williams S, (1994). Bergeys Manual of Determinative Bacteriology, 9th Edition. Lipincott Williams and Wilkins Company: Philadelphia the USA

Lehninger AL. (1995). Dasar-dasar Biokimia, Jilid 1. (Penterjemah: Maggy Thenawijaya). Principles of Biochemistry. 1982. Erlangga. Jakarta.

Marlina. (2009). Identifikasi Bakteri Vibrio parahaemolitycus dengan Metode Biologi dan Deteksi Gen ToxRnya secara PCR. Jurnal Sains dan Teknologi Farmasi. 13 (1)

Muchtadi D \& Betty SL. (1983). Petunjuk Praktek Mikrobiologi Hasil Perikanan 2. Departemen Pendidikan dan Kebudayaan. Jakarta

Palmer T. (1995). Understanding Enzymes 4th Edition. Prentice-Hall. London.

Rao MB, Tanksale AM, Gahtge MS, \& Despande VV. (1998). Molecular and Biotechnological Aspects of Microbial Proteases. Microbiology Biology Review. 62: 597- 635.

Suhartono MT. (1992). Protease. Pusat Antar Universitas Bioteknologi IPB. Bogor.

Whitaker JR. (1996). Enzymes. In Fenema O.R. Fennema (Ed.). Food Chemistry. Third Edition. Marcell Dekker, Inc., New York, and Basel

Yunita, SP. (2012) Skrining dan Uji Aktivitas Enzim Protease Bakteri dari Limbah Rumah Pemotongan Hewan. Skripsi. Fakultas Sains dan Teknologi, Universitas Airlangga. Jakarta. 